\title{
INHERITANCE OF ADULT PLANT RESISTANCE TO LEAF RUST IN FOUR EGYPTIAN WHEAT CULTIVARS AND THEIR CROSSES WITH FOUR LEAF RUST RESISTANCE MONOGENIC LINES. \\ Youssef, I. A. M. \\ Wheat Disease Res. Dept., Plant Pathology Res. Inst., A.R.C. Giza Egypt
}

\begin{abstract}
Leaf rust monogenic lines i.e. Lr27, Lr29 were crossed with four Egyptian wheat cultivars (Triticum aestivum L.,) also, Lr46 was crossed with 3 wheat cultivars and Lr2a was crossed with one cultivar (Sakha 93). These parents, F1's and F2's were tested at adult plant stage under field conditions against race mixtures of the pathogen (Puccinia triticina Eriks.) under the stress of artificial infection. The parents of monogenic lines $L r 2 a, L r 46, L r 29$ and $L r 27$ showed low disease severity. While, Gemmeiza 7, Sakha 61, Sakha 93 and Sids 1, showed high disease severity against leaf rust disease. The F1's tested plants showed low disease severity with most of crosses except three crosses i.e. Lr27 + Sakha 61, Lr27 + Sakha 93 and Lr27 + Sids 1 , which showed high disease severity. The F2 plants populations were segregated into two gene pairs. The dominance tend to the direction of low disease severity (partial leaf rust resistance) with eight crosses. However, the dominance tend to the side of high disease severity with three crosses that were previously mentioned with F1's. But no segregates was recorded with the cross $L r 2 a+$ Sakha 93 and dominance tend to the aside of low disease severity (partial leaf rust resistance). The cultivar Sakha 93 exhibited the adult plant resistance to the gene Lr2a under field conditions. These findings may prove that this gene is an effective under the Egyptian environmental conditions. The partial leaf rust resistance in the tested wheat cultivars was thought to be controlled by digenic pairs in adult plant stage. The selection for partial leaf rust resistant materials in the early generations was possible but delaying it to late ones is more effective, due to the important role of dominance effect in the expression of the character.

Keywords: Puccinia triticina Eriks. , Lrs:Leave rust resistance genes,( L.D.S):Low disease severity,(H.D.S):High disease severity, A.P.R.:Adult plant resistance, P.R.:Partial resistance.
\end{abstract}

\section{INTRODUCTION}

Leaf rust incited by Puccinia triticina Eriks, is a worldwide disease of wheat. It causes an important yield loss in temperate regions where wheat is grown. Resistance to leaf rust in wheat cultivars had always been one of the main objectives in breeding programs. The use of resistance genes represents an effective procedure and environment-friendly way to control this disease in wheat.

Meanwhile, this approach demands, a constant effort to identify, characterize and incorporate resistance gene, mainly due to the great capability of rust populations to change host response (McCallum and SetoGoh, 2005). Two slow-rusting resistance genes i.e. Lr34 and Lr46, condition nonrace-specific adult plant resistant and have provide durable leaf rust resistance (Martines et al., 2001) and Singh et al., 1998). It was reported 
about the likelyhood that $L r 34$ interacts with complementary genes $L r 27$ and Lr31 to produce enhanced resistance under conditions of high disease incidence. The role of Lr34 in comparing durable resistance to leaf rust, seems to be similar to stem rust resistance gene Sr2 (Sawhney 1992) .

In Egypt, rust diseases are the most common and dangerous of wheat plant . leaf rust, in particular, was the cause of eliminating many cultivars i.e. Giza 139, Mexpake 69, Super $x$ and Chenap 70 because of their susceptibility. It has been widespread on most cultivars of wheat grown to Egypt . After 1980, many cultivars having high level of partial resistance were produced as Giza 155 and Giza 157. Meanwhile, infection might be increased in the late sowing causing considerable losses in grain yield which reached $23 \%$ on some cultivars (Nazim et al., 1983). Adult Plant Resistance (APR) was characterized by Zadoks (1961) as a resistance which is not expressed in the seedling stage and which develops with advancing plant stages. Partial Resistance (PR) is assumed to be stable because it is polygenically inherited (Parlevliet, 1978) and is temperature insensitive (Parlevliet, 1975). PR (Partial Resistance ) is characterized by a reduced epidemic development despite a susceptible infection type (Parlevleit and Van Ommeren, 1975). The study in this investigation was carried out as an attempt to identify gene (s) for leaf rust resistance in wheat cultivars at adult plant stage.

\section{MATERIALS AND METHODS}

This investigation was carried out at the farm of Tag EL-Ezz agricultural research station Temie-Amdid Dakhlyia Egypt, aiming to identify gene(s) for leaf rust resistance in the wheat cultivars i.e. Gemmeiza 7, Sakha 61, Sakha 93 and Sids1 showing high infection type. Crossess were conducted between them and selected monogenic lines i.e. Lr27, Lr29, Lr46 and Lr2a which displayed low infection type of leaf rust resistance Table (1).

The parental cultivars and monogenic lines were grown in 2008 /2009 growing season, in three successive dates at 15 days intervals to overcome differences in the time of flowering. The monogenic lines under study were used as male parents for crosses with each of commercial cultivars Table (1). Their parents were crossed and resulted in 12 cross. The parents were sown in $1.5 \mathrm{~m}$ long rows and $30 \mathrm{~cm}$ apart. Each row was sown to 15 seed with a distance of $10 \mathrm{~cm}$. The experimental unit included 4 rows of each parent. The parents were selected according to their susceptibility or resistance on the basis of their reaction to leaf rust in the field during the elapsed growing seasons. Any doubtful of crosses hybrid seeds were discarded and the others were separately harvested.

In 2009/2010 growing season, part of the twelve (Lr's x Cvs.) cross hybrid seed were sown to produce F1's plants and the other part was kept for the final experiment in the next growing season. In 2010/2011 growing season, the evaluation of parents, F1's, and F2's, plant populations was done against natural and artificial infection with race mixtures of leaf rust pathogen caused by $P$. triticina Eriks. under field conditions. Twelve plots, each one included sixteen rows, one row for each parent and F1's as well as 13 row for 
F2 plant populations. Each row with $2 \mathrm{~m}$ long, spaced $30 \mathrm{~cm}$ apart and seeds were $10 \mathrm{~cm}$ apart within row. Each row was planted with 20 seed. The adjacent plots were separated with $1 \mathrm{~m}$ wide belt. All plots were surrounded by a spreader area of one meter in width, planted with a mixture of highly susceptible cultivars to the leaf rust pathogen i.e. Giza139, Thatcher, Triticum Spelta Saharensis and Morocco .

For the inoculation, the spreader plants were moistened and dusted with spore - powder mixture of the most prevalent leaf rust races in Egypt (one volume of fresh urediospore mixtures : 20 volume of Talcum powder) . Dusting was carried out in the early evening at (sunset) before dew formation and when air was still in. Seedlings of the susceptible wheat cultivars were placed outside after emergence. The plants were transplanted neighbour of field plots as a race nursery (Zadoks, 1964) with difference that the genotypes were randomized. On both sides and perpendicular to the spreader row, placing about 200 infected plants of the susceptible cultivar in the spreader row, just before they started to sporulate.

The inoculation of the tested plants was carried out at booting stage according to the method suggested by Tervet and Cassel (1951). Data of leaf rust severity were recorded on the adult plant stage of tested plants according to the method of modified cob scale (Peterson et al., 1948).

All regular cultural practices were applied during the growing season. Data were reported according to the technical recommendation as rust severity for each plant. Plants were divided into two classes according to level of rust severity i.e.( $0-10,11-20,21-30-31-40)$ and (41-50-51-60,61$70,71-80)$. Plants grouped in the first four classes were considered as having low disease severity (Phenotypes), while other classes (more than $40 \%$ ) were considered as having high disease severity (phenotypes) \{Negm (2004) and Shahin (2005)\}.

Statistical and genetic analysis : Frequency distribution values were computed for parental, F1 and F2 plant populations for leaf rust disease severity under field conditions. In respect to mode of inheritance, goodness of fit of the observed to the expected ratios of phenotypic classes concerning leaf rust infection types and disease severity were determined by $\mathrm{X}^{2}$ analysis according to Steel and Torrie (1960).

However, the minimal number of effective genes controlling slow rusting resistance in each cross were estimated by the formula of Wright (1968). Degrees of dominance were calculated according to the method suggested by Romero and Frey (1973). Heritability in broad - sense was estimated according to Lush (1949) as follows:

$$
\mathrm{H} 2=\frac{\mathrm{VG}}{\mathrm{VP}} \times 100
$$

Where :

$\mathrm{H} 2=$ broad - sense heritability

$\mathrm{VP}=$ phenotypic variance of $\mathrm{F} 2$ individuals

$V G=$ genotypic variance of $F 2$ individuals

$\mathrm{VE}=$ environmental variance estimated from variation with the nonsegregating populations, i.e. parent and F1 plants. 


\section{RESULTS}

The present investigation was carried out to study the inheritance of leaf rust resistance in four Egyptian commercial wheat cultivars which were crossed with four wheat monogenic lines, these parents having different levels of high and low leaf rust disease severity.

Data presented in Tables (1 and 2) were qualitatively and quantitatively analyzed as follows : Evaluation of parents, F1 and F2 plant populations against race mixtures of $P$. triticina f.sp. tritici at adult plant stage . Data obtained in Table (1) reported that the monogenic lines parents i.e. Lr2a, Lr46, Lr29, and Lr27 displayed low disease severity (partial leaf rust resistance). However, the Egyptian commercial wheat cultivars parents showed high disease severity (susceptible) fast-rusting. The twelve crosses could be arranged into two categories i.e. low disease severity (L.D.S.) and high disease severity (H.D.S.). The F1's tested plants exhibited the same trend with one parent and showed low disease severity (partial leaf rust severity) with nine crosses. However, the late three crosses recorded high disease severity i.e. Lr27+ Sakha 61, Lr27 + Sakha 93 and Lr27 + Sids 1.

Meanwhile, the F2 plant populations showed that one cross out of twelve showed no segregates i.e. (Lr2a + Sakha 93), the dominance tend to the side of partial leaf rust resistance. Meanwhile, the rest of crosses displayed segregation with numbers of plant with low and high disease severity as clarefied in Table(1) i.e. 113:97 ,170:46, 200:17, 45:164, 167:48, 200:18, 47:167, 162:47, 45:158, 191:17 and 162:45, respectively.

These observed ratios fitted the theoretical expected ratios i.e. 9:7, $13: 3,15: 1,3: 13,13: 3,15: 1,3: 13,13: 3,3: 13,15: 1$, and 13:3 with probable values 0.500 . $0.250,0.500 .0 .250,0.500 .0 .250,0.500 .250,0.250 .0 .100$, $0.250 .0 .100, \quad 0.250 .0 .100, \quad .0 .250 .0 .100, \quad 0.250 .0 .100, \quad 0.250 .0 .100$ and 0.500.0.250, respectively, Table (1) .

Quantitative analysis : The genetic behaviour of Egyptian commercial wheat cultivars to leaf rust quantitatively, the parents, F1's and F2's plant population for each of the twelve crosses were tested at adult plant stage under field conditions against race mixtures of the pathogen $P$. triticina is clarified in Table (2). Data obtained in this table explored that the disease severity (\%) recorded with eight parents i.e. Lr27, Lr29, Lr46, Lr2a, Gemmeiza 7, Sakha 61, Sakha 93 and Sids 1 were : 34.0, 24.5, 6.0, 6.0; $66.0,64.5,64.0$ and 65.5, respectively. The F1 and F2 means showed values lower than those calculated for their respective mid-parents, revealing the presence of partial dominance for low disease severity (partial leaf rust resistance) which is in accordance with the results obtained from F1's and F2's Table (2).

Expression of gene action measured as the degree of dominance h1 and h2 is shown in Table (2). The estimated values of h1 and h2 exhibited negative values in these twelve crosses suggesting the manifestation of partial dominance for leaf rust resistance and this is supported the F1's results . 
Table (1): Leaf rust severity (\%) frequency distributions of the two parents, F1 and F2 plant populations. Phenotype classes, expected ratios, $X^{2}$ and probable values of $F 2$ plant population of 12 ( $L r$ 's $\times$ Commercial cultivars) crossess as affected by inoculation with race mixtures of wheat leaf rust $(P$. triticina) at adult plant stage under field conditions in 2010/2011 grown seasons.

\begin{tabular}{|c|c|c|c|c|c|c|c|c|c|c|c|c|c|c|c|c|c|}
\hline \multirow{3}{*}{ í } & \multirow{3}{*}{ Cross name } & \multirow{3}{*}{\multicolumn{2}{|c|}{ 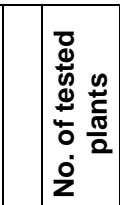 }} & \multicolumn{8}{|c|}{ Disease severity classes $\%$} & \multirow{2}{*}{\multicolumn{2}{|c|}{$\begin{array}{c}\text { Obser- } \\
\text { ved } \\
\text { ratio }\end{array}$}} & \multirow{2}{*}{\multicolumn{2}{|c|}{$\begin{array}{l}\text { Expe- } \\
\text { cted } \\
\text { ratio }\end{array}$}} & \multirow{3}{*}{$\mathrm{X} 2$} & \multirow{3}{*}{ 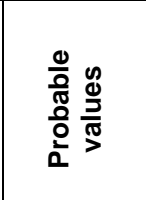 } \\
\hline & & & & \multicolumn{4}{|c|}{ Low } & \multicolumn{4}{|c|}{ High } & & & & & & \\
\hline & & & & $\begin{array}{l}0- \\
10\end{array}$ & $\begin{array}{l}11- \\
20\end{array}$ & $\begin{array}{l}21- \\
30\end{array}$ & $\begin{array}{l}31- \\
40\end{array}$ & $\begin{array}{l}41- \\
50\end{array}$ & $\begin{array}{c}51- \\
60\end{array}$ & $\begin{array}{l}61 \\
70\end{array}$ & $\begin{array}{l}71- \\
80\end{array}$ & בె & 동 & 3. & 음 & & \\
\hline & Low+High & & & & & & & & & & & & & & & & \\
\hline \multirow[t]{4}{*}{1} & Lr27 & P1 & 20 & & & 2 & 18 & & & & & & & & & & \\
\hline & Gemmeiza 7 & $\mathrm{P} 2$ & 20 & & & & & & & 18 & 2 & & & & & & \\
\hline & & F1 & 20 & & & 1 & 19 & & & & & & & & & & \\
\hline & & F2 & 212 & 5 & 18 & 40 & 50 & 46 & 32 & 19 & & 113 & 97 & 9 & 7 & 0.482 & $0.500-0.250$ \\
\hline \multirow[t]{4}{*}{2} & Lr29 & P1 & 20 & & 1 & 19 & & & & & & & & & & & \\
\hline & Gemmeiza 7 & $\mathrm{P} 2$ & 20 & & & & & & & 18 & 2 & & & & & & \\
\hline & & $\mathrm{F}-1$ & 20 & & & 3 & 17 & & & & & & & & & & \\
\hline & & $\mathrm{F} 2$ & 219 & 10 & 30 & 50 & 80 & 32 & 9 & 5 & & 170 & 46 & 13 & 3 & 0.918 & $0.500-0.250$ \\
\hline \multirow[t]{4}{*}{3} & $2 r 46$ & $\mathrm{P} 1$ & 20 & 18 & 2 & & & & & & & & & & & & \\
\hline & Gemmeiza 7 & P2 & 20 & & & & & & & 18 & 2 & & & & & & \\
\hline & & $\mathrm{F} 1$ & 20 & & 2 & 18 & & & & & & & & & & & \\
\hline & & F2 & 217 & 21 & 39 & 120 & 20 & 14 & 3 & & & 200 & 17 & 15 & 1 & 0.930 & $0.500-0.250$ \\
\hline \multirow[t]{4}{*}{4} & Lr27 & P1 & 20 & & & 2 & 18 & & & & & & & & & & \\
\hline & Sakha 61 & P2 & 20 & & & & & & 1 & 19 & & & & & & & \\
\hline & & $\mathrm{F} 1$ & 20 & & & & & 19 & 1 & & & & & & & & \\
\hline & & $\mathrm{F} 2$ & 209 & 3 & 10 & 15 & 17 & 65 & 55 & 44 & & 45 & 164 & 3 & 13 & 1.059 & $0.500-0.250$ \\
\hline 5 & Lr29 & $\mathrm{P} 1$ & 20 & & 1 & 19 & & & & & & & & & & & \\
\hline & Sakha 61 & P2 & 20 & & & & & & 1 & 19 & & & & & & & \\
\hline & & $\mathrm{F} 1$ & 20 & & & 2 & 18 & & & & & & & & & & \\
\hline & & $\mathrm{F} 2$ & 215 & & 20 & 60 & 87 & 30 & 18 & & & 167 & 48 & 13 & 3 & 1.805 & $0.250-0.100$ \\
\hline 6 & Lr46 & P1 & 20 & 18 & 2 & & & & & & & & & & & & \\
\hline & Sakha 61 & P2 & 20 & & & & & & 1 & 19 & & & & & & & \\
\hline & & $\mathrm{F} 1$ & 20 & & 18 & 2 & & & & & & & & & & & \\
\hline & & F2 & 220 & 23 & 26 & 111 & 40 & 16 & 2 & & & 200 & 18 & 15 & 1 & 1.517 & $0.250-0.100$ \\
\hline 7 & $L r 2 a$ & P1 & 20 & 18 & 2 & & & & & & & & & & & & \\
\hline & Sakha 93 & P2 & 20 & & & & & & 2 & 18 & & & & & & & \\
\hline & & $\mathrm{F} 1$ & 20 & & 19 & 1 & & & & & & & & & & & \\
\hline & & F2 & 216 & 35 & 130 & 23 & 20 & & & & & 208 & 0 & 1 & 0 & 0 & $>0.99$ \\
\hline 8 & Lr27 & P1 & 20 & & & 2 & 18 & & & & & & & & & & \\
\hline & Sakha 93 & P2 & 20 & & & & & & 2 & 18 & & & & & & & \\
\hline & & $\mathrm{F} 1$ & 20 & & & & & 19 & 1 & & & & & & & & \\
\hline & & F2 & 214 & & & 10 & 37 & 89 & 61 & 17 & & 47 & 167 & 3 & 13 & 1.448 & $0.250-0.100$ \\
\hline 9 & Lr29 & P1 & 20 & & $T$ & 19 & & & & & & & & & & & \\
\hline & Sakha 93 & P2 & 20 & & & & & & 2 & 8 & & & & & & & \\
\hline & & $\mathrm{F} 1$ & 20 & & & 2 & 18 & & & & & & & & & & \\
\hline & & F2 & 212 & & 22 & 60 & 80 & 30 & 9 & 8 & & 162 & 47 & 13 & 3 & 1.910 & $0.250-0.100$ \\
\hline 10 & Lr27 & P1 & 20 & & & 2 & 18 & & & & & & & & & & \\
\hline & Sids 1 & P2 & 20 & & & & & & & 19 & 1 & & & & & & \\
\hline & & F1 & 20 & & & & & 18 & 2 & & & & & & & & \\
\hline & & F2 & 213 & & 6 & 11 & 28 & 79 & 66 & 13 & & 45 & 158 & 3 & 13 & 1.537 & $0.250-0.100$ \\
\hline 11 & Lr29 & $\mathrm{P} 1$ & 20 & & 1 & 19 & & & & & & & & & & & \\
\hline & Sids 1 & P2 & 20 & & & & & & & 19 & 1 & & & & & & \\
\hline & & $\mathrm{F} 1$ & 20 & & & 3 & 17 & & & & & & & & & & \\
\hline & & F2 & 208 & 26 & 35 & 57 & 73 & 11 & 6 & & & 191 & 17 & 15 & 1 & 1.389 & $0.250-0.100$ \\
\hline 12 & Lr46 & $\mathrm{P} 1$ & 20 & 18 & 2 & & & & & & & & & & & & \\
\hline & Sids 1 & P2 & 20 & & & & & & & 19 & 1 & & & & & & \\
\hline & & $\mathrm{F} 1$ & 20 & & 3 & 17 & & & & & & & & & & & \\
\hline & & F2 & 204 & & 14 & 84 & 64 & 35 & 10 & & & 162 & 45 & 13 & 3 & 1.219 & $0.500-0.250$ \\
\hline
\end{tabular}

Low = low disease severity (resistance)

High = high disease severity (susceptible) 
The heritability values for all tested crosses at adult plant stage are considered to be high i.e. 96.64, 94.5, 91.25, 97.02, 94.39, 93.1, 88.25, $91.85,94.36,93.62,94.97$ and 90.82 , respectively, Table (2).

Table (2):. Mean of P1, P2, F1, F2 and mid-parents, degree of dominance of $F 1$ and $F 2$ as well as broad-sense heritability and number of genes for rust severity (\%) of 12 (Lr's x Cvs.) crosses inoculated with race mixtures of $P$. triticina under field conditions in 2010/2011 growing season.

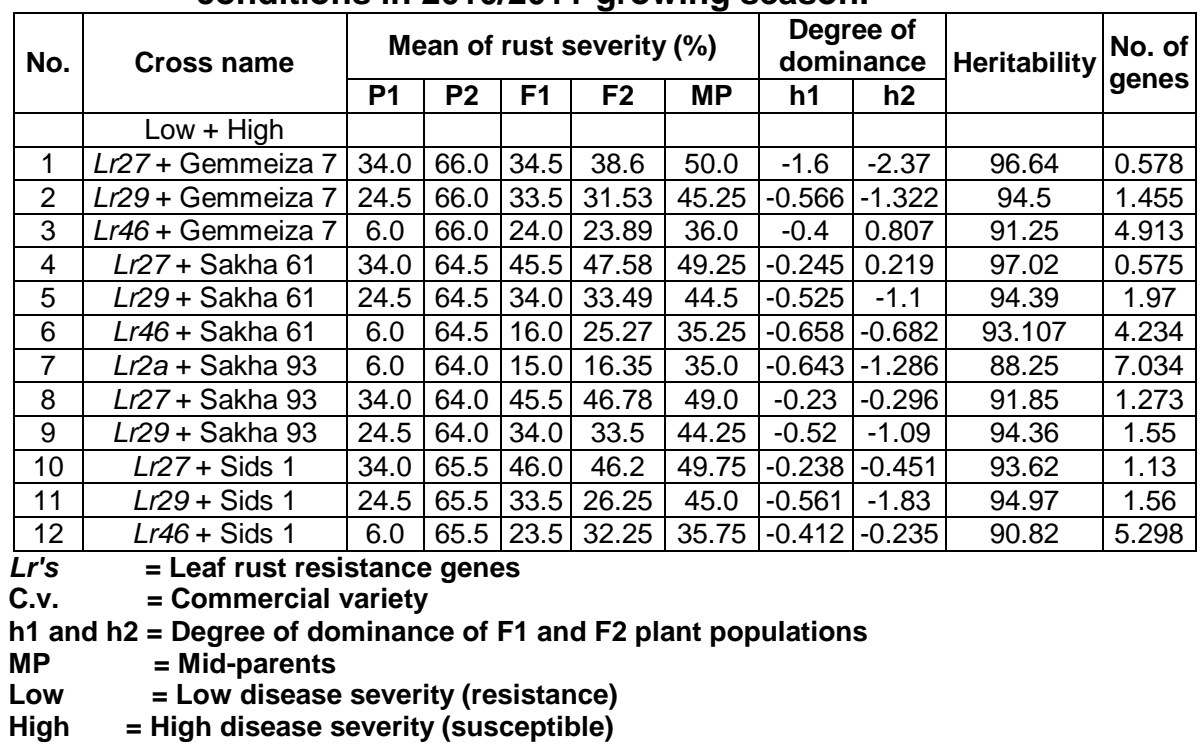

Number of genes: The minimum number of effective genes controlling the partial leaf rust resistance or susceptibility was digenic for each of the tested crosses except for the cross number seven (Lr2a + Sakha 93) that exhibited no segregation. The estimated numbers were tabulated in Table (2).

\section{DISCUSSION}

Wheat rusts are the most important diseases of wheat cultivars in Egypt. Leaf rust, in particular, was the main cause of eliminating many cultivars i.e. Giza 139, Mexpak69, Super x and Chenap70, because of their susceptibility under field conditions. Moreover, some wheat cultivars were discarded very shortly after their release such as Giza 139 (Gomma 1978). The failure of such cultivars was mainly due to the dynamic nature in population of the causal organism which produces new virulence having the ability to breakdown their resistance. However, the use of effective resistance genes is the most economic and desirable method for controlling the disease. Such information is very useful in efficient incorporation of different genes into cultivars for a long-lasting resistance. The Egyptian wheat variety 
Giza155 had high level of partial resistance under field conditions (Nazim et al., 1983). They added that, the good method to evaluate a wheat variety to leaf rust, is to test under different epiphytotic levels and different locations. Intercrosses among slow-rusting parents also were made to investigate the genetic diversity of this type of resistance (Herrera Fossel et al., 2007). Singh et al., (2000) mentioned that high yielding cultivars of bread wheat that were nearly immune to leaf rust and stripe rust could be developed by accumulating four or five slow-rusting resistance genes through intercrossing parents that show intermediate disease levels. Also, they pointed to several slow-rusting durum's identified being utilized to develop high yielding cultivars with high levels of slow-rusting resistance to leaf rust.

This investigation represents the evaluation of four monogenic lines i.e. Lr27, Lr29, Lr46 and Lr2a; and four Egyptian commercial wheat cultivars i.e. Gemmeiza 7, Sakha 61, Sakha 93 and Sids 1 under field conditions during elapsed growing seasons was carried out. All of these parents (Lr's and C.v.) showed susceptibility to leaf rust disease all over the seasons. However, Lr27, Lr29, Lr46 and Lr2a exhibited different levels of low rust severity (adult plant resistance), while Gemmeiza7, Sakha 61, Sakha 93 and sids1, showed high disease severity to leaf rust disease. The obtained results explored that most of the F1's plants displayed low disease severity (partial leaf rust resistance) slow-rusting except for three crosses i.e. Lr27 + Sakha 61, Lr27 + Sakha 93 and Lr27 + Sids 1 which showed high disease severity. On the other hand, F2's plant populations with all crosses behaved in the same trend with the F1's plants. Results of the present study demonstrated that all of the tested F2 plant populations of the cross between Lr2a + Sakha 93 displayed low rust severity with no segregations indecating that this cultivar possess this gene. These findings showed that this gene is effective under the Egyptian environmental conditions. Therefore, it may be transferred to the Egyptian genetic materials as a leaf rust resistance source in breeding programs. Oelke and Kolmar (2005) mentioned that wheat cultivar Alsen proved to have genes Lr2a, Lr10, Lr13, Lr23 and Lr34. Effective leaf rust resistance in this cultivar is conditioned by the combination of $L r 13, L r 23$ and Lr34. Also, they added that virulence to Lr2a also very common. Mclntosh and Dyck (1972) showed that in some crosses Lr23 was recessive, while in other crosses it was partially dominant. The dominance effect of Lr23 increased at higher temperature. Also they mentioned that spring wheat cultivars grown in Minnesota and Dakota may have a fairly complex inheritance of leaf rust resistance based on the genetics of Alsen and Norm. Meanwhile, the rest of crosses were segregated with digenic pairs. Results of the present study demonstrated that the F2 plants of the cross between Lr27 and wheat cultivar Gemmeiza7 showed complementary gene action with the dominance of resistance over susceptibility. The additive gene action (duplicate dominance) was shown with crossess Lr46 + Gemmeiza 7, Lr46 + Sakha 61 and $L r 29$ + Sids 1 with dominance of resistance. Also, the inhibitory gene actions were reported with Lr29 + Gemmeiza 7, Lr29 + Sakha 61 and Lr29 + Sakha 93 and Lr46 + Sids1, the resistance was dominant over susceptibility. However, the susceptibility was dominant and resistance was recessive i.e. $L r 27$ + Sakha $61, L r 27$ + Sakha 93 and $L r 27$ + Sids 1. Similar 


\section{Youssef, I. A. M.}

results were recorded by Sawhney (1992) who mentioned that the leaf rust responses of wheat lines carrying the complementary genes Lr27 and Lr31 and some genes in a Chinese spring background having Lr34, which interacts with the complementary genes gave enhanced levels of field resistance to leaf rust. Likewise, Dyck and Samborski (1982) and Ezzahiri and Roelfs (1985) showed that resistance was controlled by two complementary genes. They added that no segregation was recorded for adult plant resistance in the F2 families derived from a cross between the wheat cultivars Era and Frontana having adult plant resistance gene Lr13. Similar results were reported by Knott and Yadav (1993) who found that in eight lines, the resistance was recessive or partially recessive and was controlled by two or more genes in each line. Hussain et al., (1998) determined the leaf rust resistance genes in four wheat varieties, these varieties exhibited field resistance, probably due to additive effect of adult plant resistance genes. The durable resistance mechanism in wheat is achieved through incorporation of partially resistant minor genes which seems to be more appropriate solution for susceptible wheat production. The obtained results were in accordance with the findings of Kuhn et al., (1980); Bjarko and line (1988); Das et al., (1993); Boulat (1997); Negm (2004) and Shahin (2005) who mentioned that the quantitative analysis demonstarted that the F2 means of leaf rust severity in the eleven crosses were in general, lower than the estimated means for their respective mid-parents. These results clarified the existence of partial dominance for low disease severity in all crosses. Also, the degree of dominance ( $\mathrm{h} 1$ and $\mathrm{h} 2$ ), were significant and negative in all of the tested crosses. Similar results were confirmed by those obtained with Millus and line (1986) Shehab El Din et al ., (199la , 1991b and 1996); Youssef et al (2007).

The heritability in its broad-since estimated from parents, F1's and F2's for partial leaf rust resistance is considered to be high in magnitude, since values ranged from 88.25 to 97.02 .

Meanwhile, high heritability values are indicative for high rates of success in recovering the desired genes in future generations. These high estimates indicates that selection for this character in early segregating generations could be possible. However, delaying it would be more effective. The obtained results were in accordance with those of Bjarko and Line (1988), Das et al, (1993); Abd-EL-Latif et al., (1995); Boulot (1997); Negm (2004) and Shahin (2005). These findings would be of great importance in wheat breeding programs from the view point of disease resistance.

\section{REFERENCES}

Abd-EL-Latif, A.A.; T.M. Shehab-EL-Din; M.M. EL-Shami and S.A. Abo-ELNaga (1995). Genetics of Tritium aestivum : Puccnia recondita tritici interaction "in three Egyptian wheat cultivars ". J. Agric. Res. Tanta Univ. 21:182-188

Bjarko, M.F. and R.F. line (1988). Quantitative determination of the gene action of leaf rust resistance in four cultivars of wheat (Tritium aestivum). Phytopath. 78:451-456 
Boulot, O.A. (1997). "Further studies on leaf rust of wheat" Ph.D. Thesis, Plant Pathology. Minufiya Univ. 290 p.

Das, M.K. ; S. Rajaram; W.K. Ktonstad; C.C. Mundt and R.P. Singh (1993). Associations and genetics of three components of slow-rusting in leaf rust of wheat. Euphytica 68 (112):99-109.

Dyck, P.L. and D.J. Samborski (1982). The inheritance of resistance to Puccinia recondita in a group of common wheat cultivars. Can. J. Genet. Cytology 24:273-283 .

Ezzahiri , B. and A . P . Roelfs (1985). Inheritance of adult plant resistance to leaf rust in Era wheat. J. Phytopalhology 75:1317.

Gomma, A.S.A. (1978). Report on the Egyptian wheat varieties and their development. Egyptian Soc. of Genetics Science. Cairo.

Hussain, M.; M.H. Chaudhry; J.A. Shah and M. Younus (1998). Genetic diversity to Puccinia recondita f. sp. tritici in 59 wheat lines. Pakistani J. Phytopalhology, 10:113-121.

Herrera - foessel, S.A.; R.P. Singh; J. Huerta - Espino; J. Cross; A. Djurle and J. Yuen (2007). Evaluation of slow-rusting resistance components to leaf rust in CIMMYT durum wheat. Euphytica 155:361-369.

Knott, D.R. and B. Yadav (1993). The mechanism and inheritance of adult plant leaf rust resistance in 12 wheat lines. Genome 1993.36:877-883.

Kuhn , R.C.; H.W. Ohm and G.E. Shaner (1980). Inheritance of slow leaf rusting in suwon 85 wheat Crop Sci. 20:655-659.

Lush, J.L. (1949). Heritability of quantitative characters in farm animals. Hereditas, Supp . Vol . pp. 356-375. (cited after Weber Agro.j.44:202209).

Martinez, F.; R.E. Niks; A. Moral; J.M. Urbano; D. Rubiales and P. Hernande (2001). Search for partial resistance to leaf rust in a collection of ancient Spanish wheat. Proceeding of the fourth International Triticale Symposium. Cordoba, Spain. September 2001 Hereditas - Lund 2001,135:193-197.

McCallum, B.D. ; P. Seto - Goh (2005). Physiologic specialization of wheat leaf rust (Puccinia triticina) in Canada in 2002. Can. J. Plant Pathol. 27:90-99.

McIntosh, R.A. and P.L. Dyck (1972). Cytogenetical studies in wheat. V11. Gene Lr23 for reaction to Puccinia recondita in Gabo and related cultivars. Aus. J. Bio. Sci. 25:765-773.

Mullus, F.A. and R.F. line (1986). Gene action for inheritance of durable high-temperature, adult plant resistance to stripe rust in wheat. Phytopathology, 76:435-441.

Nazim, M.; A.A. El- Shehidi; Y.A. Abdou and Y.H. El-Daoudi (1983). Yield losses caused by leaf rust on four wheat cultivars under epiphytotic levels. $4^{\text {th }}$ confer. Microbiol., Cairo, 1983, 17-27.

Negm, S.S.M. (2004). Partial resistance to leaf rust in some Egyptian wheat varieties. Ph.D. Thesis, Faculty of Agric. Minufiya Univ. pp.192.

Oelke, L.M., and J.A. Kolmer (2005). Genetics of leaf rust resistance in spring wheat cultivars Alsen and Norm. Phytopathology. 95:773-778. 


\section{Youssef, I. A. M.}

Parlevleit, J.E. (1975). Partial resistance of barley to leaf rust Puccinia hordei. I. Effect of cultivars and development stage on latent period. Euphytica. 24:21-27.

Parleveit, J.E. (1978). Further evidence of polygenic inheritance of partial resistance in barley to leaf rust Puccinia hordei, Euphytica. 27:369-379

Parlevleit, J.E. and A. Van Ommeren (1975). Partial resistance of barley to leaf rust, Puccinia hordei. II. Relationship between field trials. Microplot tests and latent period. Euplytica 24:293-303

Peterson, R.F.; A.B. Campbell and A.E. Hannah (1948). A diagrammatic scale for estimating rust intensity on leaves and stems of cereals. Can. J. Res. 60:496-500.

Romero, G.E. and K.J. Frey (1973). Inheritance of semi dwarfiness in several wheat crossess. Crop. Sci. 13:334-337.

Sawhney, R.N. (1992). The role of Lr24 in imparting durable resistance to wheat leaf rust through gene interactions. Euphytica 61:9-12.

Shahin, S.I.M. (2005). Resistance of Gemmeiza wheat varieties to leaf rust disease Ph.D. Thesis, faculty of agric . Minufiya Univ. pp.233.

Shehab El. Din, T.M. and A.H. Abdel-Latiff (1996). Quantitative determination of the gene action of stripe rust resistance in A. parent diallel cross of wheat. j. Agric. Sci. Mansoura Univ., 10:3461-3467.

Shehab El-Din T.M.; S.A. Abd-Alla; G. El- Fadly and A.H. Abd-El-Latiff (1991a). Genetics of Triticum aestivum, Puccinia graminis tritici interaction. J. Agric. Res. Tanta Univ. 18:426-437.

Shehab El-Din, T.M.; M.A. Gouda; S.A. Abo El-Naga and M.M. El-Sami (1991b). Quantitative study on wheat resistance to stem rust caused by Puccinia graminis tritici. J. Agric. Sci. Mansoura Univ. 15:1298-1303.

Singh. R.P.; A.M. Kazi and J.H. Espino (1998). Lr46 Agene conferring slowrusting resistance to leaf rust in wheat. Phytopath .88 -890-894.

Singh, R.P.; J. Huerta-Espino; S. Rajaram (2000). Achieving near-immunity to leaf and stripe rusts in wheat by combining slow-rusting resistance genes. Acta Phytopath. Entomol. Hung. 35:133-139.

Steel, R.G.D. and T.H. Torrie (1960). Principles and procedures of statistics Mc-Graw Hill, N.Y., USA.

Tervet, I. and R.C. Cassel(1951). The use of cyclone separation in race identification of cereal rusts. Phytopath. 41:282-285.

Wright, S. (1968). Evolution and genetics of populations. vol .l. genetics of biometric foundations. University of Chicago Press. Chicago and London. 469 pp.

Youssef, I.A.M.; Gamalat, A. Hermas and M.S. Hamada (2007). Inheritance of resistance to leaf rust in 13 wheat Near - isogenic lines. J. Agric. Sci. Mansoura, Univ., 32(8):6315-6328.

Zadoks. J.C. (1961). Yellow rust of wheat : studies in epidemiology and physiologic specialization. Tijdschr. Plantenziekten. 67:69-256.

Zadoks. J.C. (1964). The use of race nurseries in cereal resistance breeding. P. 242-249. In : S. Broekhuizen, G. Dantuma, H. Lamberts and WLange (Eds). Barley Genetics I. Pudoc, Wageningen. 


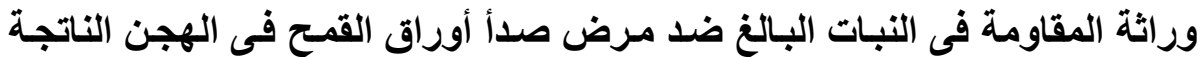

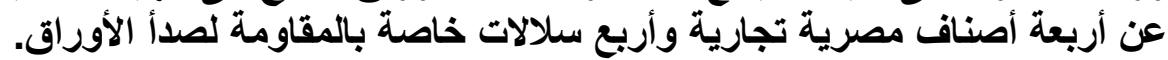

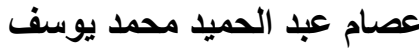
قسم بحوث أمراض القمح ـ معهد بحوث أمراض النباتات ـ مركز البحوث الزراعية ـ الجيزة- مصر.

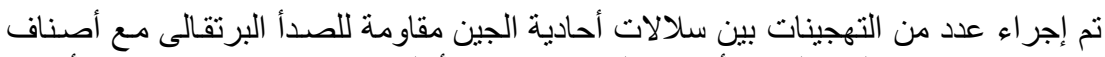

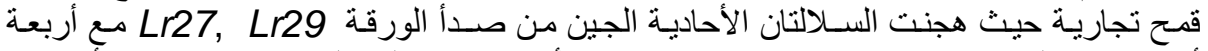

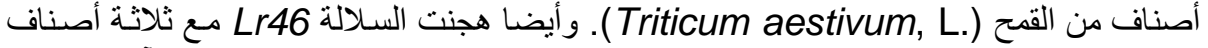

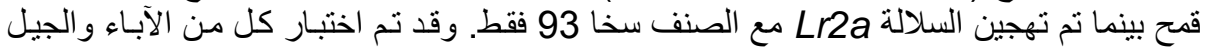

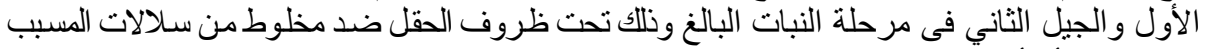
المرض لصدأ الأوراق (Puccuina triticina, Eriks. Lr27, Lr29, Lr46 قو تم تسجيل شدة المرض المنخفضة مع السلالات الأحادية الجين) . and $L r 2 a$

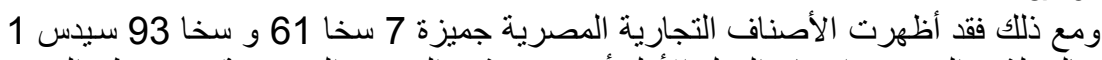

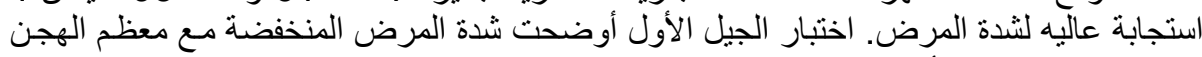

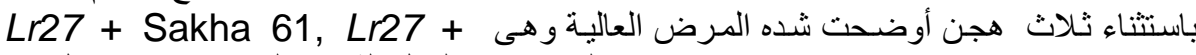
Sakha 93 and Lr27+ Sids 1

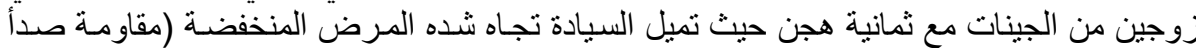

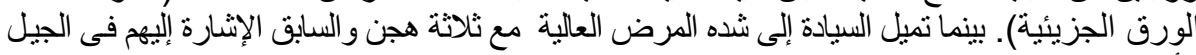

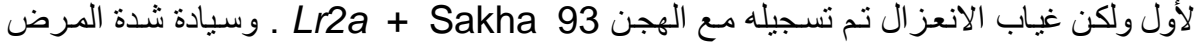

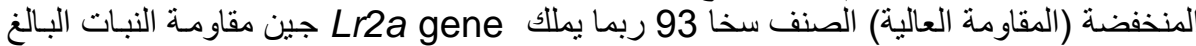

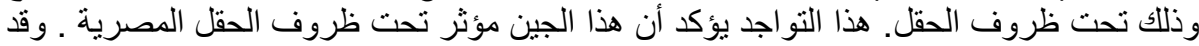

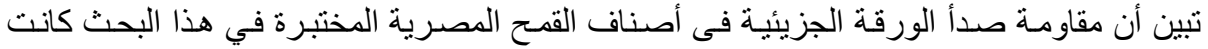

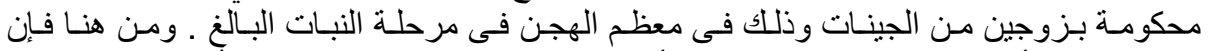

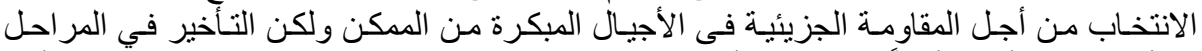

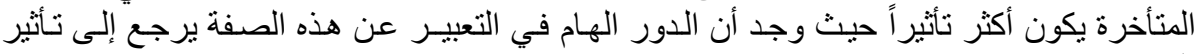
السبـادة.

كلية الزراعة بامياط - جامعة المنصورة كلية الزراعة - جامعة كفر الثيخ

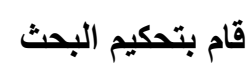

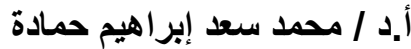
أ.د / صلاح الدين عبد الحميد أبو النجا 